\title{
Perempuan dan Kepemimpinan Gereja: Suatu Dialog Perspektif Hermeneutika Feminis
}

\author{
Bobby Kurnia Putrawan \\ Pascasarjana Sekolah Tinggi Teologi Moriah, Tangerang \\ bkputrawan@gmail.com
}

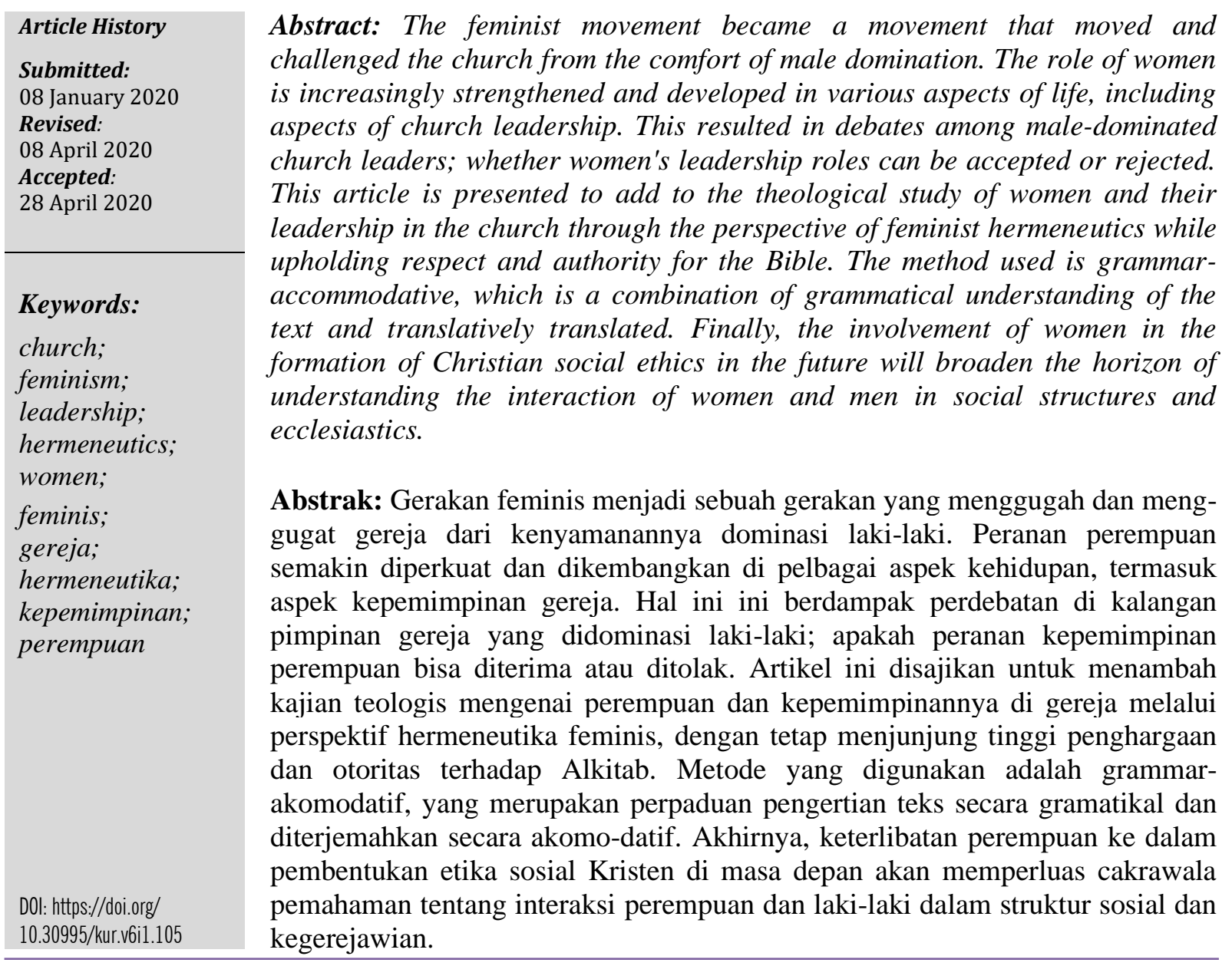

\section{Pendahuluan}

Gerakan Feminisme masuk dan menjadi suatu tantangan bagi dunia kekristenan, yang dikenal dengan teologi feminis. Isu utama dari teologi feminisme seperti yang diungkapkan oleh Paul F. Felix ${ }^{1}$, yaitu perjuangan gerakan Feminisme pada mulanya hanya untuk mendapatkan kesejajaran hak dan kedudukan perempuan ${ }^{2}$ dengan laki-laki di dalam masyarakat. Adapun pergumulan perempuan tentang hak dan kewajiban serta tanggung jawabnya telah berlang-

\footnotetext{
${ }^{1}$ Paul W. Felix, "The Hermeneutics of Evangelical Feminism”, The Master's Seminary Journal, 5(2) (1994): 159-161.

${ }^{2}$ Sudarwati D. Jupriono, Betina, Wanita, Perempuan: Telaah Semantik Leksikal, Semantik Historis, Pragmatik, FSU in the Limelight, 5(1) (July 1997).
} 
sung dalam kurun waktu yang lama. Secara sosiokultural, kebanyakan masyarakat memberikan tempat yang tidak seimbang kepada kaum perempuan dengan berbagai macam alasan, bahkan ketidak-seimbangan ini juga banyak terjadi di dalam lingkup keagamaan. ${ }^{3}$ Oleh sebab itu, hal berdampak pada munculnya gerakan perempuan untuk memperjuangkan identitas, martabat, dan hak-hak mereka.

Di beberapa gereja, pelayan perempuan adalah fenomena dalam kepemimpinan gereja. Pada generasi muda gereja sekarang bahkan mungkin tidak menyadari bahwa ada suatu masa ketika perempuan tidak diijinkan menjadi pemimpin di gereja. Selain itu, semakin banyaknya jumlah perempuan ditahbiskan sebagai pemimpin gereja, bahkan sekarang sebagian kaum perempuan sebagai pendukung amandemen hak kesetaraan dengan memberikan tekanan melalui politik, ekonomi, dan budaya. Karena itu, lebih khusus lagi, tidak mengherankan bahwa gerakan yang disebut "Feminisme biblika" telah menembus Evangelikalisme (dan/atau Fundamentalisme) serta siap untuk menantang pandangan tradisional tentang peran kepemimpinan perempuan di gereja. Pendukung utama gerakan ini adalah Nancy Hardesty, Dorothy Pape, Paul Jewett, Virginia Mollenkott, dan Letha Scanzoni dengan melandaskan bahwa lakilaki dan perempuan sederajat (Kej. 1:27) dan tidak ada perbedaan laki-laki dan perempuan (Gal 3:28). ${ }^{4}$

Pada bagian yang lain, Gangel juga menyatakan bahwa ide pokok dalam teologi feminisme adalah keberatan terhadap tradisi kekristenan tentang hubungan antara perempuan dengan keilahian. Para teolog Feminis berpendapat bahwa perempuan dapat menggambarkan Allah, baik secara penuh maupun terbatas, sama seperti Allah yang digambarkan melalui lakilaki. ${ }^{5}$ Dalam konteks Indonesia, diketahui bahwa beberapa gereja telah menerima perempuan sebagai pemimpin gereja. Meskipun perempuan diijinkan untuk menjadi pemimpin di sejumlah gereja, namun masih ada beberapa gereja yang tidak menyetujui perempuan sebagai pemimpin gereja.

Sebagian kaum Evangelikal (dan/atau Fundamentalis) menentang dan mempertanyakan apa yang harus dilakukan tentang tantangan ini? Bagaimana gerakan ini berhubungan dengan kepemimpinan di gereja? Mereka melanjutkan perkataannya bahwa masalah intinya adalah hermeneutika, penafsiran Alkitab. Dengan demikian kaum Evangelikal (dan/atau Fundamentalisme) melanjutkan bahwa yang mendasari masalah penafsiran adalah keprihatinan yang bahkan lebih mendasar dari ineransi dan otoritas Firman Allah. ${ }^{6}$ Tujuan dari penelitian ini untuk terlibat dalam penafsiran Alkitab atau dalam perspektif gereja yang berbeda yang menunjukkan apakah perempuan harus atau tidak boleh menjadi pemimpin gereja.

${ }^{3}$ Paul W. Felix, "The Hermeneutics of Evangelical Feminism", 160

${ }^{4}$ Scanzoni and Hardesty, All We're Meant to Be, 205. Lihat H. Wayne House, Paul, Women, and Contemporary Evangelical Feminism, Bibliotheca Sacra (1979), 45-46; Felix, "The Hermeneutics of Evangelical Feminism”, 161; Daniel G. Lundy, “A Hermeneutical Framework for the Role of Women”, Journal of The Baptist Review of Theology 2 (Fall 1992), 57; Harvie M. Conn, "Evangelical Feminism: Some Bibliographical Reflections on the Contemporary State of the "Union", Westminster Theological Journal, 46, (1984), 104-124.

${ }^{5}$ Kenneth O. Gangel, "Biblical Feminism and Church Leadership", Journal of Bibliotheca Sacra, 140 (557) (1983), 59; Conn, "Evangelical Feminism", 104-124.

${ }^{6}$ Felix, "The Hermeneutics of Evangelical Feminism", 163-164. 


\section{Metode Penelitian}

Ini merupakan penelitian kualitatif literatur yang berusaha mengeksplorasi prinsip-prinsip hermeneutis feminis yang diterapkan Feminis Evangelikal. ${ }^{7}$ Sedapat mungkin, evaluasi prinsip-prinsip ini akan menggunakan standar metode penafsiran akomodatif dalam kerangka pos-kolonial. Ruang lingkup dalam penelitian ini tidak memfokuskan pada prinsip-prinsip hermeneutika "hierarkis"8, yang sering digunakan dalam bagian-bagian tulisan Paulus oleh kaum Evangelikal (dan/atau Fundamentalis). Metode deskriptif juga digunakan untuk memberikan gambaran yang gambling serta proporsional tentang hermeneutika kaum Feminis ini agar dapat memberikan analisis yang seimbang. Hermeneutika Feminis dan teologi Injili memiliki spektrum pemikiran yang beragam. Paling tidak pada artikel ini hal tersebut akan dipaparkan pada landasan pemikiran yang pada umumnya dipakai masing untuk membangun landasan biblikanya. ${ }^{9}$

\section{Feminisme}

Feminisme adalah gerakan yang tersebar luas dan kompleks, yang mencakup segala sesuatu dari "hasil yang setara untuk kegiatan yang sama. Feminisme berarti bahwa perempuan harus memiliki hak yang sama dengan laki-laki dan harus diperlakukan dengan rasa hormat yang sama. Feminisme, dalam pengertian ini, adalah seruan untuk keadilan. Dalam istilah Alkitab, itu adalah panggilan untuk keadilan. Begitu orang Kristen melihat bahwa ketidaksetaraan itu tidak adil, mereka diajarkan oleh Alkitab untuk menentangnya dan menjadi pendukung keadilan bagi perempuan. Ketika kata "Feminisme" digunakan di sini tanpa kualifikasi lain, itu memfokuskan pada tujuan bersama dari gerakan Feminis, bahwa wanita adalah sama-sama manusia dengan laki-laki, dan mereka harus dianggap seperti itu dalam semua dimensi kehidupan pribadi dan publik, dan bahwa perubahan sosial yang sesuai harus dilakukan untuk memastikan bahwa perempuan diperlakukan demikian. ${ }^{10}$

Dua term istilah Feminisme sangat penting dalam konteks ini adalah untuk teologi dan gereja: (a) Feminisme Reformis dan (b) Feminisme Revolusioner (atau radikal). Feminisme reformis mengasumsikan bahwa ada banyak kejahatan dan penindasan di dalam gereja dan doktrinnya yang telah berkontribusi pada penindasan wanita, dan bahwa apa pun yang salah harus diubah. Modifikasi dan bahkan transformasi seperti itu harus terjadi dalam konteks yang mengasumsikan bahwa Allah memang nyata bagi kita di dalam Kristus, dan bahwa gereja, terlepas dari kesalahannya, adalah agen penebusan Allah. Gereja membutuhkan pertobatan, reformasi, dan rekonstruksi sesuai dengan wawasan baru yang memungkinkan Injil untuk bersinar dengan lebih benar. ${ }^{11}$

${ }^{7}$ Felix, "The Hermeneutics of Evangelical Feminism", 161-162.

${ }^{8}$ Ibid.; A. Duane Litfin, "Evangelical Feminism: Why Traditionalists Reject”, Bibliotheca Sacra, 135(543), (1979), 258-271.

${ }^{9}$ Anne Hommes, Perubahan Peran Pria \& Wanita dalam Gereja dan Masyarakat (Jakarta: BPK Gunung Mulia, 1992), 111-112.

${ }^{10}$ Patricia Wilson-Kastner, "Contemporary Feminism and Christian Doctrine of the Human", Journal of Word \& World, 2(3), 234-242; Litfin, "Evangelical Feminism: Why Traditionalists Reject”, 258-271.

${ }^{11}$ Ibid. 
Di sisi lain, Feminisme revolusioner menolak pada prinsip kekristenan (dan Yudaisme dan Islam, dan mungkin Buddhisme, Taoisme, dan lainnya), karena itu adalah konstruksi laki-laki, dan akibatnya terdapat definisi korup atas hal ini. Feminis revolusioner mengklaim bahwa perempuan hanya dapat menemukan identitas sejati mereka melalui penolakan terhadap semua agama patriarki dan pembangunan agama-agama feminis baru. ${ }^{12}$ Bagaimana selanjutnya membaca konteks kepemimpinan perempuan di gereja yang sering sangat diremehkan? Apa yang dimaksud dengan kesetaraan laki-laki dan perempuan? Apa yang harus dilakukan perihal kepemimpinan perempuan di gereja?

\section{Pembahasan}

\section{Kesetaraan Laki-laki dan Perempuan}

Kejadian 1 dan 2 memberikan dasar alkitabiah yang kuat untuk kesetaraan ontologis antara laki-laki dan perempuan. Prasangka-prasangka teologis yang membuat laki-laki, entah bagaimana, lebih unggul daripada perempuan karena prioritas kronologisnya dalam penciptaan harus ditolak. Tetapi pada teks Alkitab ini melihat seseorang untuk menambahkan pada ontologis kesetaraan konsep subordinasi fungsional. Scanzoni dan Hardesty mengungkapkan intoleransi ini dalam istilah yang kuat. ${ }^{13}$ Salah satu cara untuk mengatasi masalah ini adalah dengan menggunakan prinsip teori "akomodasi." Mollenkott seperti yang dikutip Conn, misalnya, mengatakan bahwa "Alkitab tidak salah mencatat proses pemikiran Paulus," tetapi ia kemudian menjelaskan bahwa alasan Paulus menulis apa yang ia lakukan adalah untuk mengakomodasi dirinya sendiri ke budaya Rabinik. ${ }^{14}$

Tetapi, di mana orang menarik garis pada teori akomodasi? Jika para penulis Alkitab dikondisikan secara budaya, siapa yang menentukan bagian Alkitab mana yang memiliki otoritas absolut dan bagian mana yang hanya berkaitan dengan masalah seperti misalnya, gereja di Korintus? Terlebih lagi, jika akomodasi adalah hermeneutik Paulus, cara ia menyesuaikan pemahamannya tentang firman Tuhan dengan situasi budaya kontemporernya, bagaimana dengan bahaya penilaian hakim pada hari ini? Teori akomodasi selalu mengurangi otoritas dan ineransi Alkitab. Hal itu menempatkan Alkitab pada belas kasihan penerjemah modern, yang memungkinkan ia untuk membawa prasangka yang bias ke dalam teks. ${ }^{15}$

Menurut Gangel, salah satu argumen Feminis yang diajukan menentang subordinasi fungsional adalah, bahwa Yesus sering mengklaim Ia tunduk kepada Bapa (namun tidak kalah setara dalam keilahiannya) menggambarkan kedudukan sementara, suatu status yang hanya

\footnotetext{
${ }^{12}$ Patricia Wilson-Kästner, "Christianity and the New Feminist Religions”, Journal of Christian Century, 98, (1981), 234-242, 864-868; Rosemary Ruether, "Goddesses and Witches: Liberation and Countercultural Feminism”, Journal of Christian Century, 97 (1980), 842-847; Litfin, "Evangelical Feminism: Why Traditionalists Reject", 270-271.

${ }^{13}$ Kenneth O. Gangel, "Biblical Feminism and Church Leadership", Journal of Bibliotheca Sacra, (1983): 58-61; James Alexander, "Against Feminism and Beyond Silence: The Biblical View of Female Ministry", Brethren Life and Thought, 30 (1985), 231-236); Wilson-Kastner, "Contemporary Feminism and Christian Doctrine of the Human", 236-240; Band: Conn, "Evangelical Feminism", 104-124; Litfin, "Evangelical Feminism: Why Traditionalists Reject", 260-261.

${ }^{14}$ Conn, "Evangelical Feminism", 104-124; Don Williams, The Apostle Paul and Women in the Church, 112; Band: Gangel, "Biblical Feminism and Church Leadership", 59.

${ }^{15}$ Gangel, "Biblical Feminism and Church Leadership", 59; Felix, "The Hermeneutics of Evangelism Feminism”, 160.
} 
dimiliki selama masa inkarnasi. Tetapi, 1 Korintus 15:27-28 menunjukkan kelemahan kesimpulan itu: "Karena ia 'telah meletakkan segala sesuatu di bawah kakinya." Sekarang ketika dikatakan bahwa 'segala sesuatu' diletakkan di bawahnya, jelas bahwa ini tidak termasuk Allah sendiri, yang meletakkan segala sesuatu di bawah Kristus. Ketika ia melakukan ini, maka Anak itu sendiri akan menjadi tunduk kepadanya yang meletakkan segala sesuatu di bawahnya, sehingga Tuhan menjadi segalanya". ${ }^{16}$ Lebih lanjut Gangel menjelaskan sama seperti Yesus yang sederajat dengan yang lebih rendah dari Bapa, demikian pula seorang istri sama dengan yang lebih rendah dari suaminya. Ini sama sekali tidak ada hubungannya dengan chauvinisme, superioritas, atau ketidaksetaraan. Ini adalah masalah cara fungsi berfungsi dengan baik di gereja. Seseorang dapat meninggalkan posisi ini hanya dengan menolak otoritas pengajaran Alkitab yang jelas. Tujuan hermeneutis semacam itu membawa beberapa evangelikal tradisional ke dalam konfrontasi langsung dengan feminisme dalam barisan mereka sendiri. ${ }^{17}$

Menurut Royden pandangan itu sama sekali tidak mungkin bagi mereka yang telah memikirkan sikap Kristus terhadap kepribadian manusia. Paulus kadang-kadang menegaskan dengan catatan inspirasi terbesar bahwa di dalam Kristus tidak ada laki-laki atau perempuan, dan di tempat lain ia menegaskan bahwa ada ketidaksetaraan rohani antara jenis kelamin, dan bahwa kepala laki-laki adalah Kristus tetapi kepala perempuan adalah laki-laki. Inilah inti masalahnya. Pada pendapat ini, penulis mengkritik pendapat Royden yang menilai adanya ketidaksetaraan rohani antara jenis kelamin pada tulisan Paulus di 1 Korintus 11:3 tanpa melihat teks dan konteks. Menurut penulis, Paulus sedang menjelaskan adanya kondisi jemaat Korintus yang sedang dalam kondisi ketiadaan ketertiban dalam gereja. Dengan demikian Paulus hendak memberikan nasehat kepada jemaat di Korintus untuk hidup dalam ketertiban, dimana Royden menyadari bahwa ini merupakan pernyataan khusus. ${ }^{18}$ Dengan kata lain Royden hendak mengatakan adanya ambiguitas dari tulisan Paulus, yang dimana ini telrihat dari tulisan Royden yang mengatakan "Paulus membuat dua pernyataan besar, yang salah satunya menegaskan kesetaraan pribadi dan spiritual masing-masing dalam Kristus, "laki-laki dan perempuan, ikatan dan kebebasan," dan di tempat lain membuat pernyataan yang tidak dapat diselaraskan dengan itu."19 Laki-laki dan perempuan didorong kembali untuk membandingkan pengajaran itu dengan ajaran Kristus, dimana semua orang percaya baik lakilaki dan perempuan adalah sama dan memiliki hubungan langsung dihadapan Tuhan.

Ini berarti bahwa perbudakan harus berjalan pada akhirnya, dan itu benar-benar juga berarti bahwa asumsi bahwa perempuan ada hanya sebagai jenis kelamin untuk menjadi ibu atau menjadi pelacur, bahwa mereka ada hanya karena mereka adalah jenis kelamin, atau, sebagai ungkapan penting yang digunakan untuk menjadi, "jenis kelamin"-itu benar-benar berarti

\footnotetext{
${ }^{16}$ Ibid., 60; Litfin, "Evangelical Feminism: Why Traditionalists Reject”, 258-271; Felix, Ibid. 161.

${ }^{17}$ Ibid.

${ }^{18}$ Philip B. Payne, "Wild Hair and Gender Equality in 1 Corinthians 11:2-16", Priscilla Papers, 20(3) (Summer 2006), 9-15; D. V. Palmer, "1 Corinthians 11: 1-16 A Rhetorical Reading”, Caribbean Journal of Evangelical Theology, 15 (2016), 77-94; Alan Padgett, "Paul on Women on the Church: The Contradictions of Coiffure in 1 Corinthians 11:2-16", Journal for the Study of the New Testament, 20 (1984), 69-86; James A. Sanders, "The Bible as Canon", The Christian Century, 98 (1981), 1250-1255.

${ }^{19}$ A. Maude Royden, Introduction: Prophetic Feminism in Religion, Journal of Sewanee Theological Review, 54(4) (2011): p. 366.
} 
bahwa sikap itu juga harus pergi. Bukan, untuk saat ini yang ditekankan adalah, pekerjaan apa yang akan dilakukan saat ini yang menjadi intinya. ${ }^{20}$ Artinya, apakah seseorang akan dianggap oleh masyarakat secara keseluruhan dari pekerjaan terbaik apa yang bisa dilakukan, atau dari sudut pandang apa yang paling nyaman bagi laki-laki lakukan. ${ }^{21}$

James A. Sanders ${ }^{22}$ mengungkapkan dengan menarik perihal penemuannya yang sangat membantu dalam menerapkan Kitab Suci mengenai masalah wanita. Dia menggambarkan subdisiplin baru dari "kritik kanonik" yang mendorong kejujuran tentang pluralisme Alkitab. Memperhatikan bahwa Kitab Suci memuat banyak kanon yang telah mendapat pengakuan melalui komunitas-komunitas yang beriman, Sanders mengatakan, apa yang ada di dalam teks tidak hanya ada karena seseorang di zaman itu diilhami untuk mengucapkan kata yang diperlukan kepada komunitasnya, tetapi juga karena komunitas itu sangat menghargai komunikasi untuk mengulanginya dan merekomendasikannya kepada generasi berikutnya dan ke komunitas di dekatnya. Apa yang disebut bagian sekunder mewakili apresiasi masyarakat dalam menyesuaikan pesan dengan kebutuhannya, dan mereka menunjukkan kepada kita, dengan menggunakan alat penting yang diperlukan, bagaimana mereka melakukannya.

Alkitab sebagai kanon adalah produk komunitas dalam pengertian ini. Kegagalan untuk mengakui pluralisme dalam Alkitab adalah tidak jujur, kata Sanders, tetapi kegagalan untuk mengenali nilai pluralisme berarti kehilangan harta dari perbedaan-perbedaan di dalam Alkitab. Ia mengatakan, di antara banyak hal berguna lainnya, bahwa "pluralisme kanonik menjamin tidak ada konstruksi yang dapat dibangun di atas Alkitab yang tidak dihakimi, dan berharap ditebus oleh sesuatu yang lain di dalamnya. Tuhan adalah Tuhan, bukan Alkitab atau kanon di dalam kanon dari satu posisi apa pun yang dibangun di atasnya. Manusia dijauhkan dari absolutisasi Feminisme, atau sikap tunduk perempuan, atau rasisme, atau nasionalisme kita, atau kebebasan dan kesetaraan karena selalu ada kata lain dalam Alkitab untuk menantang kemutlakan konstruksi manusia. Jika upaya untuk memonetisasi (menunggalkan) dan menegaskan integritas Tuhan saja dilakukan, maka tidak ada dalam semua ciptaan yang dapat diklaim; tidak ada berhala; sebaliknya politeisme direduksi menjadi pluralisme, yang menurut penilaian Tuhan, bisa menjadi berkah. ${ }^{23}$

Wilson-Kastner ${ }^{24}$ mengungkapkan komunitas yang hidup di dalam Kristus perlu dibuat dengan kesatuan global dalam pikiran. Tidak ada ruang privat dan moralitas publik, tidak ada etika pribadi Kristen yang ketat di samping kebutuhan pragmatis dari hubungan nasional dan internasional. Setiap keputusan manusia, dari yang paling tersembunyi hingga tingkat tertinggi, diplomasi internasional, sebenarnya dibuat dalam konteks persatuan komunitas manusia, tentu saja, kosmik. Peran etika Feminisme adalah untuk menjelaskan konteks sebenarnya dari keputusan yang dibuat, dan membantu bertanggung jawab untuk bergulat dengan keterkaitan semua yang dilakukan. Feminisme tidak hanya berkontribusi pada pengakuan kemanusiaan penuh perempuan, tetapi juga menerangi dan memperkuat dimensi penting dari iman yang

\footnotetext{
${ }^{20}$ A. Maude Royden, "Introduction: Prophetic Feminism in Religion”, Journal of Sewanee Theological Review, 54(4) (2011), 365

${ }^{21}$ Ibid.

${ }^{22}$ James A. Sanders, "The Bible as Canon", 1250-1255.

${ }^{23}$ Ibid.; Peggy Ann Leu Shriver, "Christians and/or Feminism, Foundations" 25(2) (1982), 167-179.

${ }^{24}$ Wilson-Kastner, "Contemporary Feminism and Christian Doctrine of the Human", 242.
} 
sepenuhnya alkitabiah. Jadi dapat dikatakan bahwa ide Wilson-Kastner, yaitu kesetaraan lakilaki dan perempuan dalam satu kesatuan dalam Kristus, maka hal ini memiliki konsekuensi etis yang sangat spesifik yang dihadapi oleh komunitas Kristen.

\section{Kepemimpinan Perempuan dalam Gereja}

Diperlukan keseimbangan antara legalisme kaku yang terlalu sering menandai kepemimpinan laki-laki di jajaran Evangelikal (dan/atau Fundamentalis) dan penahbisan yang berupaya merestrukturisasi Alkitab untuk mengakomodir trend modern. Inti dari perdebatan adalah dugaan konflik antara konsep alkitabiah tentang kepemimpinan ( $\varepsilon \varphi \alpha \lambda \eta ́)$ dan penyerahan (

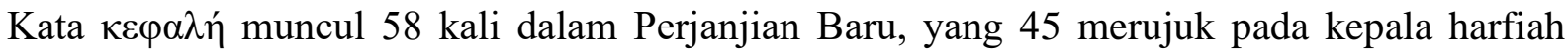
/fisik dan 13 adalah kiasan. Banyak bagian simbolis berbicara tentang Kristus, Kepala gereja (Ef. 1:22; 4:15; Kol 1:18; 2:10, 19). Dua bagian (Ef. 5:22-24 dan 1 Kor. 11:1-16) menghadirkan kesulitan dalam penafsiran. Dalam Efesus 5: 22-24, Paulus mendasarkan seruannya untuk tunduk pada prinsip kekepalaan: "Hai isteri, tunduklah kepada suamimu seperti kepada Tuhan. Sebab suami adalah kepala isteri sama seperti Kristus adalah kepala gereja, tubuhnya, di mana dia adalah Juru Selamat. Sekarang sebagaimana gereja tunduk kepada Kristus, demikian juga istri harus tunduk kepada suami mereka dalam segala hal. " Dalam 1 Korintus 11: 1-16, inti permasalahan muncul dalam ayat 3: "Sekarang aku ingin kamu menyadari bahwa kepala setiap laki-laki adalah Kristus, dan kepala perempuan adalah laki-laki, dan kepala Kristus adalah Tuhan." Argumen umum feminisme biblikal dalam bagian-bagian ini

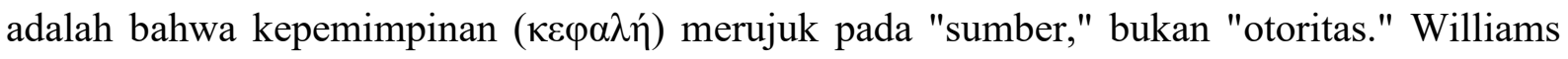
menyatakan pandangan ini secara ringkas dari Efesus 4:15-16 dan 5:23. ${ }^{25}$

Williams secara akurat mengungkapkan prinsip ketergantungan dan pemodelan. Namun, premisnya salah. Mengabaikan 45 referensi Perjanjian Baru tentang penggunaan fisik $\kappa \varepsilon \varphi \alpha \lambda \eta ́$, ia mengasumsikan hermeneutika tertentu mengenai ayat-ayat simbolis Kristus sebagai sumber (bukan Otoritas) gereja dan segera menerapkannya kepada suami dan istri. ${ }^{26}$ Tetapi dalam pengertian fisik, apakah benar secara biologis mengatakan bahwa kepala adalah sumber kehidupan? Apakah kepala terbentuk pertama dan kemudian seluruh tubuh? Apakah nutrisi fungsi tubuh benar-benar berasal dari otak atau bagian lain dari tengkorak? Tentu saja tidak. Kepala adalah pusat kontrol untuk tubuh. Otak mengidentifikasi dengan tepat perilaku apa yang harus diikuti oleh bagian-bagian tubuh, sehingga "kontrol" atau "otoritas" adalah analogi yang jauh lebih baik dari dunia fisik daripada gagasan "sumber."

Tentu saja, penerapan spiritualitas kepada Kristus dan gereja mengikuti, terutama ketika seseorang membaca Perjanjian Baru dalam terang perintah terakhir Tuhan (Mat. 28: 18-20). Pola otoritas dari bagian ini diperkuat oleh kata Yunani $\varepsilon \xi o v \sigma i ́ \alpha$ ("otoritas"). Kristus menjelaskan kepada para murid bahwa Ia memang Kepala gereja; Ia memegang kendali. Susan Foh mempertimbangkan berbagai pilihan 1 Korintus 11:1-16 dan menekankan bahwa fokus pengajaran Paulus dalam ayat-ayat yang sulit ini adalah menyembah Allah dengan cara yang memuliakan Dia. ${ }^{27}$ Ia menyimpulkan bahwa kepemimpinan harus dipahami dalam konteks

\footnotetext{
${ }^{25}$ Don Williams, The Apostle Paul and Women in the Church (Deridale, CA Regal Books, 1977), 112.

${ }^{26}$ Ibid.

${ }^{27}$ Susan T. Foh, Women and the Word of God: A Response to Biblical Feminism (Phillipsburg, NJ: Presbyterian and Reformed Publishing Company, 1980), 105.
} 
itu. Mungkin dalam satu hal pernyataan "kepala perempuan adalah laki-laki" (1 Kor. 11: 3) dapat diartikan secara harfiah.

Mungkin laki-laki disebut kepala perempuan karena posisi yang Allah tunjuk kepadanya dalam pernikahan dan di dalam gereja (berpotensi). Secara umum "kekepalaan" laki-laki akan menjadi sesuatu seperti gelar kehormatan, tentu saja tidak dipahami sebagai menempatkan setiap perempuan di bawah otoritas laki-laki tertentu, apakah ayah, saudara lelaki, atau pendeta. Yang pasti, seluruh pertanyaan tentang penutup (apakah kain, rambut, atau sikap) rumit, tetapi Foh memperkenalkan tujuan yang mungkin menarik untuk dimasukkan. ${ }^{28}$ Tetapi,


alkitabiah, masalah penyerahan adalah seruan perang. Bagian-bagian kunci termasuk 1 Korintus 14:34; Efesus 5: 22-24; Kolose 3:18; 1 Timotius 2:11; Titus 2: 5; dan 1 Petrus 3: 13. Kata $v \pi o \tau \alpha ́ \sigma \sigma \omega$ adalah istilah logistik yang merujuk pada pengaturan peralatan militer di medan perang untuk peperangan yang efektif. Ini berfokus pada fungsi, bukan esensi.

Paulus menulis: "Perempuan harus tetap diam di gereja-gereja. Mereka tidak diperbolehkan berbicara, tetapi harus tunduk, seperti yang dikatakan oleh Hukum Taurat" (1 Kor. 14:34); ini diakui sebagai ayat yang sulit. Jewett segera menolaknya sebagai cerminan tradisi Rabinik yang dipertahankan oleh Paulus, seorang Farisi yang baik. Scanzoni dan Hardesty berpendapat bahwa kata "berbicara" ( $\lambda \alpha \lambda \varepsilon \dot{\varepsilon} \omega)$ tidak merujuk pada bentuk nasihat atau pengajaran, tetapi hanya untuk menghasilkan pembicaraan yang biasa-biasa saja atau kosong. ${ }^{29}$ Namun, kata Yunani ini tidak dapat dibatasi secara sempit. Orang bisa berharap analisis mereka tentang kata itu akan bertahan, karena itu menawarkan penjelasan sederhana dari sebuah ayat yang sulit. Apakah "berbicara" di sini merujuk pada berbicara dalam bahasa roh, sesuatu yang dilarang untuk perempuan di Korintus? Lebih mungkin, itu berarti dialog verbal terbuka di sinagoga atau tempat ibadat umum, sebuah praktik yang mungkin mengarah pada perebutan peran mengajar di mana laki-laki terlibat.

Tetapi semua ini tidak menghilangkan kenyataan tunduk. Apa yang dipertaruhkan di sini, seperti yang ditunjukkan sebelumnya, adalah komitmen terhadap otoritas Alkitab dan ineransi teks asli. Dinilai oleh tulisan-tulisan mereka sendiri, para feminis alkitabiah tidak mau membuat komitmen seperti itu. Menulis sebagai seorang perempuan dan sebagai teolog yang dipercaya, Foh menjabarkan masalah utamanya. ${ }^{30}$ Dalam konteks ini, kaum Feminis revolusioner tidak percaya bahwa Allah telah memberikan kita firman-Nya yang benar dan dapat dipercaya, standar yang tidak berubah untuk percaya dan mempraktikkannya. Sebaliknya, kita memiliki informasi (beberapa di antaranya adalah kata murni Tuhan, dan beberapa hanya nasihat manusia, dibentuk oleh budaya yang dikuasainya), dan Tuhan telah meninggalkan kita sendiri untuk mencari tahu bagian mana yang harus ditaati dan percayai. ${ }^{31}$

Masalah yang paling jelas adalah penahbisan. Dalam Roma 16:1-2 apakah pujian Paulus tentang Phoebe harus ditafsirkan sebagai penugasan kepadanya sebagai jabatan diaken? Foh

\footnotetext{
${ }^{28}$ Ibid., 7.

${ }^{29}$ Letha Scanzoni and Nancy Hardesty, All We're Meant to Be (Waco, TX: Word Books, 1975), 68; William C. Weinrich, "Feminism in the Church: the Issue of Our Day", Concordia Theological Quarterly, 50(2) (1986), 142.

${ }^{30}$ Yarbrough, "Women and Ministry", 68, 70, 74; Band: Foh, Women and the Word of God, 164-166.

${ }^{31}$ Ibid., 71.
} 
mempercayai bahwa penugasa Phoebe sebagai jabatan diaken adalah benar. ${ }^{32}$ Pertama, suatu kasus terisolasi dari satu diakon perempuan hampir tidak menjadi argumen yang kuat untuk penahbisan perempuan sebagai penatua dan diaken di gereja baik abad pertama atau hari ini. Kedua, perikop penting yang mengidentifikasi kualifikasi diaken (1 Tim. 3: 8-13) tidak

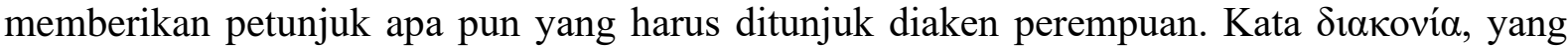
menggambarkan "layanan" atau "pelayanan" secara umum, umum dalam Perjanjian Baru

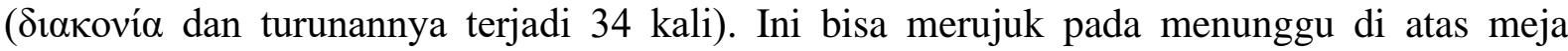
(Lukas 10:40), menawarkan dukungan keuangan (Kis. 11:29), dan sejumlah jenis layanan

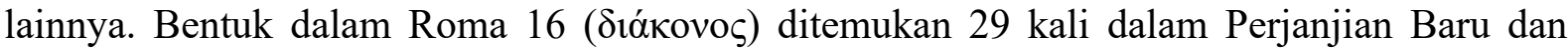
digunakan terutama untuk menggambarkan orang yang melayani di meja. ${ }^{33}$

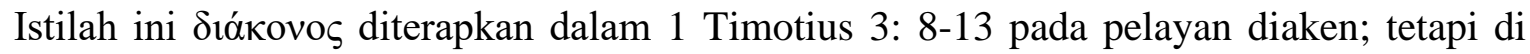
banyak tempat lain, seperti "sepupu pertamanya" $\delta 1 \alpha \kappa o v i ́ \alpha$, ini berbicara tentang pelayanan umum. Masalah penting lainnya yang sering muncul di kalangan evangelikal adalah pertanyaan apakah perempuan harus mengajar di gereja. Meskipun beberapa bagian mengenai masalah ini, 1 Timotius 2:11-14 mungkin yang paling sulit. "Seorang perempuan harus belajar dalam ketenangan dan penyerahan penuh. Secara lebih luas dan jelas, Padgett menawarkan pandangan dari Gangel bahwa perempuan dapat mengajar atau memiliki wewenang atas seorang laki-laki; dia tidak harus diam. Hal ini berkaca bahwa surat Paulus kepada Timotius berdasarkan konteks situasi pastoral pada saat itu. Jika melihat keseluruhan tulisan maka bisa dilihat tidak ada pemisahan pandangan antara laki-laki dan perempuan dalam melayani gereja. $^{34}$

Perikop ini tidak berhubungan dengan hubungan suami-istri tetapi dengan status perempuan mana pun di sidang umum. Perikop 1 Korintus 14:34 ini tentu dapat menekankan peran pengajaran yang diambil (atau diasumsikan) dan menempatkan perempuan dalam peran yang lebih rendah daripada kepemimpinan dalam gereja. Dalam konteksnya, perintah tersebut didasarkan pada hubungan laki-laki dan perempuan dalam penciptaan asli (Kejadian 2:18; 3: 6). Williams berupaya menyelesaikan masalah dengan mengatakan bahwa perikop ini hanya merujuk pada gereja di Efesus selama masa kepemimpinan Timotius di sana. ${ }^{35}$

Williams mungkin memiliki poin penting; dia berhasil menghindari jebakan akomodasi. Namun, mungkin lebih baik untuk memahami bahwa Paulus mengatakan bahwa perempuan tidak merebut atau memegang otoritas (kuasa) atas laki-laki. Peningkatan seorang perempuan ke posisi kepemimpinan sesuai dengan Alkitab, asalkan itu telah diberikan kepadanya oleh Allah (melalui dia dipilih oleh para pemimpin gereja lain) dan bukan hasil dari konflik suksesnya sendiri di arena politik kekuasaan. Yang dipertaruhkan di sini adalah kesetiaan

\footnotetext{
${ }^{32}$ Foh, Women and the Word of God, 188-189.

${ }^{33}$ Gangel, "Biblical Feminism and Church Leadership", 61; Alan Padgett, "Paul on Women on the Church: The Contradictions of Coiffure in 1 Corinthians 11:2-16", Journal for the Study of the New Testament, 20 (1984), 69-86; Philip B. Payne, "Wild Hair and Gender Equality in 1 Corinthians 11:2-16", Priscilla Papers, 20(3), (2006), 9-18.

${ }^{34}$ Padgett, Ibid.; Payne, Ibid; Band: Gangel, Ibid.

${ }^{35}$ Williams, The Apostle Paul and Women in the Church, 64-65; Gangel, "Biblical Feminism and Church Leadership", 56; Padgett, Ibid. 69-86; Payne, "Wild Hair and Gender Equality", 9-18.
} 
pada firman Tuhan, seperti yang digambarkan House. ${ }^{36}$ Mungkin ada sedikit pertanyaan bahwa pelanggaran terhadap feminis (revolusioner) yang disebutkan di atas dalam hal inspirasi melampaui batas-batas yang dapat diterima dalam teologi evangelikal. Jika bidang pertikaian mungkin dihilangkan hanya dengan seruan sosialisasi, maka interpretasi tidak memiliki kontrol, dan gagasan wahyu terbatas atau tingkat inspirasi hampir tidak dapat dihindari. Apakah argumen Paulus tentang doktrin dosa datang dari satu orang untuk diabaikan dalam pandangan studi antropologis kontemporer? Atau dapatkah dikatakan bahwa Paulus hanya meminjam ide-idenya tentang dosa asal dari teologi ke-rabi-an? Ini jelas harus dijawab dalam negatif. ${ }^{37}$

Tetapi pertanyaan sebenarnya adalah apakah seseorang akan tunduk pada firman Tuhan yang diungkapkan Galatia 3:28, "Tidak ada orang Yahudi atau orang Yunani, hamba atau orang merdeka, laki-laki atau perempuan, karena kamu semua adalah satu di dalam Kristus Yesus", menekankan tanggung jawab orang percaya lebih dari hak-hak perempuan. Memang, jika orang Kristen pada umumnya lebih menekankan tanggung jawab dari pada hak-hak mereka. Tentu saja respon yang tepat adalah penegasan semua orang percaya dari pada penciptaan hierarki berdasarkan jenis kelamin seseorang. Dengan demikian di masa depan, gereja perlu meningkatkan peran perempuan dalam komunitas gereja, peningkatan itu tidak boleh dicapai dengan kekakuan atau sebaliknya penyerahan teks Alkitab pada setiap penafsir. ${ }^{38}$

Suatu usulan yang menarik ditawarkan oleh seorang Feminis reformis, Conn dan Royden, berpendapat sama, yaitu keyakinan teologis mendasar yang diartikulasikannya dalam banyak konteks adalah kesetaraan spiritual mutlak antara laki-laki dan perempuan yang ia temukan di pusat ajaran-ajaran Kristus. Pengalamannya tentang ketidakmampuan gereja untuk berbagi dan mewujudkan keyakinan ini semakin menyakitkan. Ia menganjurkan untuk menerima semua panggilan yang sah, termasuk apa yang pada akhirnya akan dia kenali sebagai panggilannya sendiri untuk menjadi imam. ${ }^{39}$

Conn mengusulkan bahasa tradisional mungkin perlu diperiksa ulang dalam hal ini. Apakah konsep alkitabiah tentang "ke-kepala-an" (kepemimpinan) laki-laki secara memadai memakai bahasa yang masih dipahami dalam budaya Chauvinis sebagai penjagaan simbol kontrol verbal, kepemimpinan, dan subordinasi. Hubungan peran membutuhkan wawasan sosiologi dan antropologi budaya saat kita memeriksa teks-teks Alkitab lagi. Budaya membentuk pemahaman tentang peran dalam interaksi manusia, sehingga peran membentuk citra diri. Manusia memiliki peran ganda yang masing-masing dilakukan dalam masyarakat; perlu ditemukan inti dan titik bersama. Alkitab dapat berperan dalam membedakan antara diri "nyata" ini dan kepribadian sosial-budaya. Selain itu, bahasa memengaruhi komunikasi antara

\footnotetext{
${ }^{36}$ Williams, The Apostle Paul and Women in the Church, 112; Payne, Ibid.; Gangel, Ibid., 56-57; Alexander, "Against Feminism and Beyond Silence", 234-245; Yarbrough, "Women and Ministry: Fidelity to Scripture in the Unity of the Faith", 70, 74; House, "Paul, Women, and Contemporary Evangelical Feminism", 43-44.

${ }^{37}$ Ibid.; Padgett, "Paul on Women on the Church", Payne, Ibid., 9-18., Band: House, Ibid., 45-53; Yarbrough, Ibid. 68.

${ }^{38}$ Conn, "Evangelical Feminism", 110-112; Padgett, 69-86; Payne, Ibid., 9-18.; Band: John E. Alsup, "Imagining The New: Feminism, Galatian 3:28 and the Current Interpretive Discussion", Austin Seminary Bulletin, 105 (1990), 91-108; Yarbrough, Ibid., 77; Gangel, "Biblical Feminism and Church Leadership", 63.

${ }^{39}$ Royden, "Introduction: Prophetic Feminism in Religion", 361; Conn, Ibid., 111; Alsup, Ibid. 96-98.
} 
peran yang diasumsikan secara budaya, sehingga di saat bersamaan Alkitab berfungsi sebagai korektif di sini juga. ${ }^{40}$

Dalam Alkitab, laki-laki dan perempuan menemukan panggilan untuk keadilan yang menuntun mereka untuk mendukung prinsip bahwa perempuan harus diperlakukan sama dengan laki-laki. Dalam Alkitab mereka juga menemukan, bahwa Tuhanlah yang membuat manusia menjadi laki-laki dan perempuan, yang berarti bahwa jenis kelamin manusia adalah hal yang baik. Selain itu, dalam Alkitab Allah disebut dengan istilah-istilah maskulin seperti raja dan Tuhan memanggil perempuan untuk melayani sebagai pelayan di gereja. ${ }^{41}$

Dapat dikatakan bahwa Tuhanlah yang memberikan panggilan, dan itu adalah usaha gereja dengan semua perhatian dan keterampilannya untuk menentukan siapa yang memilikinya, dan siapa yang tidak. Tetapi bukan bagi Gereja untuk memberikan panggilan itu. ${ }^{42}$ Ini adalah milik Allah. Kita akan menemukan bahwa calon pimpinan gereja yang terpilih. Apakah ia benar-benar percaya bahwa Roh Kudus telah memanggilnya untuk panggilan ini? Dan jika Roh Kudus memanggilnya, itu menjadi tugas gereja untuk memberinya pelaksanaan jabatannya. Panggilan itu diberikan oleh Allah dan gereja perlu berhati-hati secara cermat memikirkan pertanyaan tentang penerimaan perempuan sebagai imam. ${ }^{43}$ Jadi, merujuk dari diskusi di atas, maka teori akomodatif tidak selalu bernilai negatif seperti yang diusukan oleh Conn dan Royden di atas.

Kebaikan bersama menjadi prinsip dasar pemikiran kekristenan adalah pengakuan pribadi manusia tidak hanya sebagai individu tetapi juga sebagai sosial. Martabat individu paling baik diwujudkan dalam kebaikan bersama masyarakat. Kebaikan bersama didefinisikan sebagai 'jumlah total dari semua kondisi kehidupan sosial, ekonomi, politik, budaya, dan gereja yang memungkinkan laki-laki dan perempuan dengan mudah serta penuh untuk mencapai kesempurnaan kemanusiaan mereka'. Hubungan antara individu ini dan kebaikan bersama dalam kekristenan adalah kontribusi uniknya bagi pemahaman kita tentang tatanan sosial. ${ }^{44}$

Feminisme dapat menunjuk pada prinsip ini sebagai tantangan bagi Gereja untuk memperluas pemahamannya tentang kebaikan bersama dalam hubungannya dengan perempuan dan juga perempuan dalam hubungannya dengan kebaikan bersama. Margaret Farley menunjukkan bahwa dari sudut pandang tradisi etika Kristen (Katolik), adalah kesalahan untuk mengadu kebaikan individu melawan kebaikan komunitas atau kebaikan sosial. ${ }^{45}$ Bagian tradisi ini bertentangan dengan gagasan membatasi perempuan dalam fungsi atau tugas tertentu. Farley lebih jauh berpendapat dari sudut pandang subsidiaritas, prinsip pemikiran sosial Kristen, bahwa model hirarkis dalam struktur sosial apa pun harus memberi jalan kepada model organisasi sosial yang egaliter jika kebaikan bersama ingin direalisasikan.

\footnotetext{
${ }^{40}$ Conn, "Evangelical Feminism”, 124; Alsup, “Imagining The New”, 102-103.

${ }^{41}$ Fisher Humphreys, Feminism and the Christian Faith, Journal of The Theological Educator, 52 (1995), 15-20.

${ }^{42}$ Peter F. Murphy, "Learning from Women," dalam Oxford Reading in Feminism: Feminism \& Masculinities, (New York: Oxford University Press, 2004), 51.

${ }^{43}$ Royden, "Introduction: Prophetic Feminism in Religion", 372.

${ }^{44}$ Peter J Henriot, Edward P DeBerri, Michael J Schultheis, Catholic Social Teaching: our Best Kept Secret, (Maryknoll, N.Y: Orbis Books, 2003), 7-19; Maria Riley, "Catholic Social Thought Encounters Feminism", The Way: Journal of Contemporary Christian Spirituality, 31(2) (1991), 160.

${ }^{45}$ Margaret Farley, New Patterns of Relationship in Woman: New Dimensions, ed by Walter Burkhardt. (New York, Paulist Press, 1977), 68; Riley, Ibid.
} 
Menerapkan prinsip ini pada hubungan antara perempuan dan laki-laki, ia menyimpulkan: 'Perlu diperdebatkan bahwa sebenarnya kebaikan keluarga, gereja, dan lainnya, lebih baik dilayani oleh model kepemimpinan yang mencakup kolaborasi antara orang-orang yang setara'. ${ }^{46}$ Prinsip-prinsip kebaikan bersama dan subsidiaritas menuntut persamaan dan mutualitas tidak hanya dalam hubungan pribadi tetapi juga dalam struktur sosial.

\section{Kesimpulan}

Kesimpulannya adalah masalah ini bukan untuk menyangkal atau merendahkan peran sosial dan nilai perempuan yang memilih membesarkan anak dan mengurus rumah tangga sebagai pekerjaan utama mereka. Melainkan untuk membawa ke dalam perspektif peran ganda dan potensi perempuan. Lebih lanjut dapat dikatakan bahwa untuk menekankan perempuan pada tanggung jawab atas kualitas kehidupan keluarga tanpa mengurangi peran sosial dan nilai kebapa-an. Hal ini tidak menghilangkan hak laki-laki dari peran laki-laki sebagai ayah, tanpa menghilangkan hak perempuan dari potensi kepribadiannya.

Sebuah pembacaan hermeneutika Feminis tentang sebagian pemikiran Feminis dengan jelas mengungkapkan bahwa itu tidak secara akurat mencerminkan pengalaman mayoritas perempuan di dunia kontemporer. Membawa pengalaman hidup perempuan ke dalam pembentukkan etika sosial Kristen di masa depan akan memperluas cakrawala pemahaman tentang interaksi manusia; manusia-perempuan dan laki-laki-dalam struktur sosial dan kegerejawian. Ini juga akan memberikan perspektif Feminis Kristen-perempuan dan lakilaki-untuk terlibat dalam dialog dengan ideologi feminisme kontemporer dalam membentuk masa depan tatanan sosial dan kepemimpinan gereja. Baik feminisme dan pemikiran sosial kekristenan akan diperkaya oleh dialog ini. Dalam konteks gereja-gereja di Indonesia, ketika komunitas mencari solidaritas melintasi kekhasan dan perbedaan, maka mungkin menjadi dasar bagi dialog dan praksis bersama. Sarannya, gereja melupakan pembacaan Alkitab tanpa tubuh yang mengarah pada konstruksi teologis tanpa tubuh. Sebaliknya, memasukkan cerita naratif orang lain sambil mengakui hak istimewa sendiri adalah langkah pertama dalam "menanggung beban satu sama lain"" Paling tidak kesadaran seperti ini membuat gerejagereja di Indonesia dapat bertumbuh sesuai dengan konteks dan kebutuhan dari masingmasing gereja dengan masing merespon panggilan Tuhan di dunia ini.

\section{Referensi}

Alexander, James. Against Feminism and Beyond Silence: The Biblical View of Female Ministry, Brethren Life and Thought. 30. (1985): 231-236.

Alsup, John E. Imagining the New: Feminism, Galatian 3:28 and the Current Interpretive Discussion. Austin Seminary Bulletin. 105. (1990): 91-108.

Conn, Harvie M. Evangelical Feminism: Some Bibliographical Reflections on the Contemporary State of the "Union". Westminster Theological Journal. 46. (1984): 104124.

Farley, Margaret. New Patterns of Relationship' in Woman: New Dimensions. ed Walter Burkhardt. New York: Paulist Press, 1977.

Felix, Paul W. The Hermeneutics of Evangelism Feminism. The Master's Seminary Journal. 5(2). (1994): 159-184.

\footnotetext{
${ }^{46}$ Margaret Farley, New Patterns of Relationship in Woman..., p. 68; Maria Riley, Catholic Social Thought Encounters Feminism: p. 160-161.
} 
Foh, Susan T. Women and the Word of God: A Response to Biblical Feminism. Phillipsburg, NJ: Presbyterian and Reformed Publishing Company, 1980.

Gangel, Kenneth O. Biblical Feminism and Church Leadership. Journal of Bibliotheca Sacra. 140(557). (1983): 55-63.

Henriot, Peter J.; DeBerri, Edward P.; Schultheis, Michael J. Catholic Social Teaching: our Best Kept Secret, Maryknoll, N.Y: Orbis Books, 2003.

Humphreys, Fisher. Feminism and the Christian Faith. Journal of The Theological Educator. 52. (1995): 15-20.

Litfin, A. Duane. Evangelical Feminism: Why Traditionalists Reject. Journal of Bibliotheca Sacra. 135(543). (1979): 258-271.

Murphy, Peter F. Learning from Women, dalam Oxford Reading in Feminism: Feminism \& Masculinities, New York: Oxford University Press, 2004

Royden, A. Maude. Introduction: Prophetic Feminism in Religion. Journal of Sewanee Theological Review. 54(4). (2011): 361-373.

Padgett, Alan. Paul on Women on the Church: The Contradictions of Coiffure in 1 Corinthians 11:2-16. Journal for the Study of the New Testament. 20. (1984): 69-86.

Palmer, D. V. 1 Corinthians 11: 1-16 A Rhetorical Reading. Caribbean Journal of Evangelical Theology. 15. (2016):77-94.

Payne, Philip B. Wild Hair and Gender Equality in 1 Corinthians 11:2-16. Priscilla Papers. 20(3). (2006): 9-15.

Riley, Maria. Catholic Social Thought Encounters Feminism. The Way: Journal of Contemporary Christian Spirituality. 31(2). (1991): 150-162.

Sanders, James A. The Bible as Canon. The Christian Century. 98. (1981): 1250-1255.

Williams, Don. The Apostle Paul and Women in the Church, Deridale, CA Regal Books, 1977.

Shriver, Peggy Ann Leu. Christians and/or Feminism. Foundations. 25(2). (1982): 167-179.

Weinrich, William C. Feminism in the Church: the Issue of Our Day. Concordia Theological Quarterly. 50(2). (1986): 139-144.

Wilson-Kastner, Patricia. Contemporary Feminism and Christian Doctrine of the Human. Journal of Word \& World. 2(3). (1982): 234-242.

Yarbrough, Robert W. Women and Ministry: Fidelity to Scripture in the Unity of the Faith. Journal of Prebyterion. 35(2). (2009): 65-81. 